\title{
People and Nature in Asian Stories: Reading and Writing Materials for Eco Education
}

\author{
Novita Dewi \\ Universitas Sanata Dharma, INDONESIA \\ e-mails: novitadewi@usd.ac.id
}

\begin{abstract}
The purpose of this article is to make parents/teachers/writers of children literature aware of eco education through stories about people and nature. Written through the eyes of a child, many conservation stories not only empower the young minds, but they also help adults change their attitude to respect environment. The first part of this article examines such environmental stories as fables, folklores, short stories from Asia, while the second part is a project report on writing eco education materials, i.e. a serial of 3 environmental stories for young adults. Using Ecocriticism and Postcolonial perspectives to analyze the stories, the study shows that the narrative strands found in the stories include (1) depletion of the earth and natural resources, (2) people's greediness, and (3) preservation of the traditional wisdom. Some stories are still anthropocentric so as to provide no space to explore fully the human-nature relationship in a balanced way. Although animal stories dominate the narratives, it is the specific and philosophic depiction of place and nature that give the stories Asian characteristics in their shared campaign to save our planet. This study concludes that the call for environmental protection can be done through young adult literature in a non-condescending manner instead of the usual patronizing-colonizing method.
\end{abstract}

Keywords: Ecocriticism, traditional wisdom, anthropocentric views.

\section{INTRODUCTION}

Contrary to the belief that children are innocent and should be protected from learning about harsh realities of life; and that children's literature should be simple, sweet and sugary, it is important that teachable lessons are present in the books young people read. Environmental degradation is now an impending tough reality that people including children have to face, hence the urgency to raise ecological awareness since the young age. Such messages as environmental conservation, respect for nature, care for all living things can be covered through fables, folklores and other narrative forms, because naturally children like to listen to stories. Children's literature can therefore be used as a medium for environmental education (Lindenpütz 2002). This is to say that while enjoyable to read, children's literature should reflect human conflicts, values and character education (Livo 2003), expand engagement and provide critical thinking (Wolf
2004), so as to challenge the patronizing motives and ideology that adults often infested in reading materials for children (Nodelman, 2008).

However, problems may occur since books of this kind are often hard to find as shown by several studies on children's literature and ecology. Examining children's environmental literature, for example, the work of Gaard (2009) is an intersection of ecofeminism and studies on environmental justice with which she offers six criteria for an ecopedagogy of children's environmental literature. Her study reveals that most books do not meet the criteria.

Similarly, Ramos and Ramos (2015) argue that children's literature may sometimes fail to promote knowledge and attitude toward ecological issues effectively, given the often simple, happy, and at times, magical solutions to problems of the world around them. Using Discourse Analysis, Ramos and Ramos look at recent children's literature in Portugal

\footnotetext{
* The genesis of this article is a paper earlier presented in the Fourth Literary Studies Conference held in Universitas Sanata Dharma on 19 20 October 2016 and appeared in the proceeding Children's Literature in Southeast Asia (Yogyakarta: English Letters Department, 2016), pp. 254 - 259. This study was sponsored by the Ministry of Research and Technology of the Republic of Indonesia 2016 (Year Two of the Fundamental Research Scheme).
} 
to claim that ecoliteracy may be advocated or devalued through the narratives of people's interaction with their social, physical, and cultural setting.

Meanwhile, Massey (2009) examines 19 picture books and 4 novels for children published in between 1999 and 2006 to conclude that fictional ecological subjects in the texts under study are constructed to cater to the contemporary state's ideology about environment which is understandably anthropocentric.

These studies have all contributed to not only new perspectives in studying children's literature (i.e. practical, therapeutic reading for pleasure v. critical and engaged reading), but also environmental discourse that has become increasingly important today. Lamentably, while useful, none of the studies above put Asia into the picture. Gaard, Ramos and Ramos and Massey explore children's literature in, respectively, Germany, Portugal and Australia. This article, therefore, attempts to discuss what and how environmental messages are carried in stories set in Asia. The objectives of this article, therefore, are twofold, i.e. to promote eco education to make parents/teachers/writers of children literature aware of eco education by offering first an Ecocritical analysis of environmental stories primarily set in Asia and, secondly, presenting what kind of stories for young people is suitable to use as eco education materials, especially in Indonesia.

\section{LITERATURE REVIEW}

The power of stories to touch human's heart is hard to deny, especially for the young people because generally they love to hear and tell stories. It is through stories that children learn about how things work (and do not work) and why we do what we do. Parkinson quotes Ben Okri about the transforming power of tales: "Stories are as ubiquitous as water or air and as essential. There is not a single person who is not touched by the silent present of stories" (2009: 15). The easiest way to teach children about hygiene, water consumption, recycling and other environmental lessons is through story-telling. Parkinson likens the children's learning process to that of smokers, alcoholics, gamblers, etc. when told straightforwardly to stop their compulsive bad habits. These unrepentant addicts, like children, are quick to resist the good advice and obstinately follow their own, wrong, ways. Tales, on the contrary, transform people. Pollution, animal rights, deforestation, global warming are such issues that may sound less daunting when conveyed through folktales, legends, short stories, etc.
Meanwhile, O'Brien and Stoner (1987) define environmental education in terms of people who are knowledgeable about the world and the sustainable development thereof. As it is, measurements for ecoliteracy include awareness of (1) basic needs shared by people and wildlife, (2) interdependence of the living and nonliving elements, (3) people's affect to the environment and vice-versa, and (4) people's responsibility to protect the environment (O'Brien and Stoner, 1987: 14). Teaching with the School of Education at California State University in San Bernardino, California, Kathy O'Brien and Darleen Stoner use mainly American books for children to use as either reading materials or discussions/activities related to environment.

While the two teachers' guidance is helpful here, stories with Asian contexts are important to document so that the universal concern of environmental protection can be more palpably shared especially in Asia and other parts of the world where global injustice as warned by Pope Francis is most real. In Encyclical No. 25 of Laudato si' released in 2015, the Pope mentions that the worst effects of global warming and climate change are profoundly felt by the developing countries, especially the poor and the marginalized. They are the most affected and disadvantaged, because their livelihood depends on nature reserves and ecosystem stability, such as agriculture, forestry, fisheries, and other bounty of nature. The poor people have no access to financial resources that allow them to adapt in the face of climate change or natural disasters. Neither do they obtain protection and adequate social service (See Dewi, 2015). Mindful of the ever present eco-injustice in Asia, this study seeks to find out how environmental issues appear in Asian writing.

Next, while this present study owes significantly to the studies cited above, Postcolonial perspectives are also useful and complementary. The wealth of scholarships on children's literature (e.g. Nodelman, 2008; Bradford, 2007) has shown that relations of power and knowledge is clear in books for children as well as school textbooks in that Western imagination and interpretation continues to prevail. Postcolonial literary studies challenge this universalizing and colonizing reading by shifting the focus on the local, particular and indigenous narratives. If one agrees with Ashcroft and others (1989) about the trauma and impact of colonialism toward the postcolonial societies, any accounts on people and nature should address the power-relation significations. Here, the ex-colonizer's (read: Western) dominance over the place highlights the supremacy of the West over other visions or ways of looking at things. 
Introducing stories about people and nature in their very own environment as well as sense of place, in this case, Asian origin is thus a postcolonial strategy. Borrowing the aforementioned concepts and the counter-narrative reading technique (e.g. Marzec, 2007; Massey, 2009), this current study is to analyze first several chosen stories about people and nature. Afterward, to quote Ashcroft in Post-colonial Transformation, "colonialism brings with it a sense of dislocation between the environment and the imported language now used to describe it" (2001: 152). Imported ecological stories are aplenty, but the ones written in Bahasa Indonesia are needed for eco education. The second part of this study attempts to do so.

\section{METHOD OF STUDY}

Being part of a bigger project, this article limits itself to the reading of selected texts (short stories, fables, folktales, songs, poems) that talk about people and their environment. The data source is mainly drawn from Cerita-Cerita Pelestarian Lingkungan: Cerita Rakyat dari Berbagai Penjuru Dunia (2003). This book is the Indonesian translation of MacDonald's Earth Care - World Folktales to Talk About published first in 1992 and often used in eco education worldwide (Ellis 2012). There are about 13 (thirteen) stories from the book to examine in this study: "The Farmer and His Crops" (Hmong), "Hold Tight and Stick Tight" (Japan), "The New Lake" (China), "Fox Rules the Stream" (Thailand), "The Mosquito Extermination Project" (India), "Gecko Cannot Sleep" (Bali), “Avvaiyar's Rest” (Tamil Nadu), "Hidden Divinity" (India), "Love the Weeds" (Iran), "The Useless Tree" (China), "Sharing the Wine" (China), "In Your Hands" (India), "The Tamarind Tree" (Thailand) and "Don't Throw Stones from "Not Yours" to "Yours" (Israel). Other materials include 3 (three) short stories published in the children's section of Kompas Sunday edition. The texts discussed are chosen based on some preliminary analysis through Ecocritical lenses. Ecocriticism is used to see if each narrative places people's interests over nature (anthropocentric), or instead critically looking at the degradation of nature. Textual analysis is applied to see if natural conservation becomes the primary concern in the narrative. Here, Ecocriticism and Postcolonial are used as perspectives in reading the stories to answer the basic two questions:

(1) In what ways do the stories depict the relationships between nature and human beings?

(2) Is there domination over nature by people?

Next, for the purpose of comparison and contrast analysis, this study also examines the trilogy of
Alamku, Sayang [O, Nature of Mine] by Prapta Diharja - prototype of environmental stories for young adult readers resulted from the research project.

\section{RESULTS AND DISCUSSIONS}

\section{Reading Green Stories for Environmental Awareness}

When dealing with the reading materials for young people, Shelby A. Wolf's concept of literary engagement (2004), in particular, is applied, focusing as it does on her notion of reading to learn vis-à-vis learning to read. People-nature relationship is central to the texts in different levels of engagement seen from ecocritical and postcolonial perspectives.

To begin with stories taken from MacDonald's book, paratextual analysis is quick to claim that the narratives revolve around caring for the earth as indicative of the book's title. As a worldwide folklorist, story teller and children's book expert, MacDonald presents a story book with comprehensive notes on each story, clustered under different ecological themes. Each story is accompanied as closing by related proverb or quotation to highlight the message. She also provides a short bibliography of tale collections with ecological messages; source and notes of proverbs and tales cited; a list of good stories to tell.

Unlike MacDonald's own thematic categorization of the tales shown in 13 (thirteen) chapter titles, this article classifies the stories set in or originated from Asia and/or Asian culture into 5 (five) main themes in the light of Ecocriticism and Postcolonial Criticism. The themes are (1) environmental care, (2) impacts of people's behaviour toward nature, (3) interconnectedness of natural life (4) valuable things on earth and (5) human greed. In each theme, features of ecoliteracy claimed by O'Brien and Stoner (1987) are invariably shown.

The first theme is the need to care for our environment, i.e. forests, rivers, wetlands, etc. that give us life. Today's biggest problem is our marred connectivity with the natural world - we hurt the earth and we hurt ourselves. Our task is instead to preserve land well to pass it on to the next generation. That people have a choice to use or abuse nature is clear in "The Farmer and His Crops" and "In Your Hands". The first is a Hmong folktale on the origin of brief harvest time. A farmer is too lazy to work in his field letting weeds to grow. He too is reluctant to reap the crops. Corn and rice are said to go voluntarily to the farmer's house, and much to their disappointment, they find no barn built for them. Off they run back up 
to the hill because they cannot stay long. From then on, farmers have to toil harder up and down the hill to gather their harvest. The second story, a legend from India, is of similar morality tale. Also said in different parts of the world, this legend has some Biblical ring thus: We reap what we saw. A smart-alecky young man attempts to challenge a reportedly wise man to ask if the bird in his hand is dead or alive. "If I say the bird is alive", answered the wise man calmly, "you will kill it; or let it fly away if I say it's dead", hence the title of the story. And so it is with the way we choose how to live and, accordingly, treat people and nature around us. This study would argue that, in view of Ecocriticism, people still occupy a prevailing position in ecological relationships. The care for environment is largely for people's needs, not for nature's sake.

The second theme is impacts of each person's action to society as in the anecdote from China about wine sharing that ends up with a feast of water under the moon light because everyone decides to pour a jug of water into the barrel feeling sure that no one knows if one jug only is mixed into the wine. Problem of pollution starts when one is ignorant of others and lack of understanding that people need to work together to keep this earth planet alive. This pollution story is resonant in the Jewish story. The tittle of the story 'Don't Throw Stones from 'Not Yours' to "Yours" does the work to reprimand readers about the bad, inconsiderate trashing habits. A once rich man keeps throwing out unwanted stones from the front yard of his big house onto the street. He hardly listens to any complains about his selfish littering. The table is turned when he is later broke. What a nuisance for him to find plenty of stones on the street in front of the neat and clean backyard of the house which is now no longer his property. Here, people's colonizing attitude toward nature and other people is shown in the two stories originated from non-Western tradition. Although both stories are universally applicable, it is hard to ignore that within these ecological messages, being stingy and selfish are stereotypically worn by, respectively, Chinese and Jewish characters. Seen from Postcolonial perspectives, the discourse of the dominant, positive West over other (Non-Western) civilizations is implied herein, if subtly.

According to O'Brien and Stoner (1987), ecoliteracy can be measured if, among others, the story describes the interdependence of the living and nonliving elements (14). That all things are connected is the third message as shown by "Gecko Cannot Sleep" and "The Mosquito Extermination Project" about disturbance by the existence of others. Here, the absence of any living being may disturb chains of life for all creatures on earth. Feeling disturbed by Fireflies' blinking their lights on and off at night, a gecko goes to the Village Head to complain, receives chain explanation from different parties, understands and gets back to sleep. Fireflies blink to light the road for people in order that they do not step on Buffalo's dunk. Buffalo fills the street holes that Rain washes out. Rain has to come so that Ponds won't dry up. If the ponds dry up, Mosquitoes will die and Gecko has nothing to live on. MacDonald explains that the Gecko story is told by her Balinese story-teller friend Made Taro (1999: 152). Notably, cycle-of-life-chain story is popular in Indonesia as proven by the similar storyline found in children's traditional song about the frogs by the river calling for the rain to come for everyone's good. It can be argued here that a story from Indonesia, although still small in number, has contributed to the collections of global ecological stories. As for, "The Mosquito Extermination Project", this Indian story is also about how everything around us is linked to each other.

The fourth message is that nothing in this world is without value. "Love the Weeds" and "The Useless Tree" at first seem anthropocentric. People do not want to own anything that hardly benefits them straightaway. This theme overlaps with the stonedumping-Jew-story. People want to get rid of plants or other creatures that seemingly of no use. Although on the surface these stories sound pro-people, it can be argued that ecocritical motif is clear here. "The New Lake", similarly, is a story of development blunder. The Chinese Prime Minister plans to clear a lake to make a way for bigger plot of land. Upon his confusion about where to throw away the water from the lake, his deputy says that he, too, would like to build a new lake of exactly the same size next to the old one, hence the doomed plan. Unnecessary manipulation of nature by people is no recommendation. Here, care for nature is also an idea shared by the two Indian/Tamil Nadu stories MacDonald put under the heading Our Place in Earth's Sacred Place, i.e. "Avvaiyar's Rest" and "Hidden Divinity". Both stories talk about the sanctity of nature created by God. God is everywhere. Similarly, in Laudato si', Pope Francis says that people who do not love nature cannot love people; and thus to love God is impossible.

Finally, the fifth message is destructive power of greed shown by those who never think that enough is enough as evident in the stories from Japan and Thailand. The Japanese story depicts the narrative in binary opposition - reward for the good character and punishment for the greedy one. The former is told to 
hold tight to the magical pine tree from which its sap turns into gold. The later wants to stick tight to the same tree as long as he wants only to find that its sap flushes into his entire body. The first of the stories from Thailand, "Fox Rules the Stream", is about the battle between the small and big animals. Driven by voracity, one sly fox uses its power to order big animals like pythons and elephants to bully small creatures living in the river with which the fox lives on. Thanks to the rabbit who mobilizes other small animals to combat the big ones. The second Thai story is softer in approaching the subject of greed. In "The Tamarind Tree", two friends set out their journey to make a better living and promise to each other to meet again after five years. One is successful because of her perseverance and thrift, the other is a failure due to her insatiable consumptions. The former then gives a shelter to the later in a small house at the backyard with a tamarind tree. The loser does not use this second chance but continues indulging herself by plucking the tamarind tree leaves to put into her meal for flavor, thus leaving the tree barren. The best friend comes again for rescue and lecture to make her realize her mistakes of recurrently wanting "just a little bit more". In both stories, no ecological moral lesson is clearer than Mahatma Gandhi oft-used quote being "Earth provides enough to satisfy people's need but not people's greed".

The discussion now turns to the three short stories appeared in the children's section of the Sunday's Kompas. Seen from Ecocriticism, all of them intend to raise ecological awareness to the readers with differing degree of success. "Menanam Bakau" [Growing Mangrove] and "Warisan Mbah Amat" [The Inheritance of Mbah Amat] speak of the need to save the earth for the next generation because people do not inherit nature from their ancestors to use at will. Blatant ecological message is clear in these stories set respectively in Medan and the village of Bantul, Yogyakarta about growing mangrove and planting seeds for the future descendants. The last story set in Flores "Putri Alor" [Princess Alor] tells of a girl who appreciates the wonder of green turtles on the coast of Alor island she plays with every day. At first, her mother disapproves of this outdoor activity, but the older one later realizes that the oft-forgotten treasures under the sea are in need of protection. Unlike the previous two stories, this story from Flores does more justice to ecological and postcolonial interpretations since this eastern region of Indonesia is given due recognition. Note must be taken here that the dominant culture tends to be postcolonizing in that national culture is often taken to mean Java or metropolitan-centered culture. As also shown by Massey (2009), Aboriginal nature stories, for exam- ple, are rarely featured in Australian texts. Using stories originating from different parts of Indonesia to raise ecological awareness, this article would argue, is recommended because ecological conservation and ecological conversion, to use Pope Francis' words, is our responsibility in protecting the earth as our common home.

To sum up, most stories studied talk more about people and their interaction with nature. Only a few stories posit nature in central position. The portrayal of nature is always seen in its usefulness for people. As reading materials for young adults, these texts are simple and honest about people's attitude toward nature, i.e. the good is rewarded, the bad, punished. The stories are also rich in Asian philosophies, particularly about good moral conducts. Indeed, as observed by Donelson-Sims (2013), literature teaching in Indonesia, for example, is rife with moral lessons so as to kill, sometimes, the joy of learning itself. Nevertheless, despite the pro-people approach in dealing with the environmental issues, the texts studied are appropriate to use as ecoeducation materials.

\section{Writing Green Stories for Eco Education}

This part examines how recognition of homegrown local stories to use in eco education is to challenge the universalizing and colonizing gesture of the West as being the epitome and sources of all wisdom and knowledge. Sense of dislocation, says Ashcroft, is obvious when local, familiar place to us is absence in the narratives (2001: 153).

It must be mentioned here that the larger research project upon which this article is based explores works, authors and green literature communities. The nature of the research itself combines textual analysis of text and their contextualization with $\mathrm{R} \& \mathrm{D}$ type of research Alamku, Sayang [O, Nature of Mine] is a labour of love by Prapta Diharja being one of the research team members. Diharja is a Jesuit Priest, writer and keen gardener in his residence at St. Bellarmine's Chapel, Mrican, Yogyakarta and, occasionally, in his hometown, Wedhi, Klaten, Central Java. Meant as a prototype for green writing, that is, literature about ecology, the Alamku, Sayang series consists of three books entitled Menyambut Mentari [Welcoming the Sun], Kering Kemarau [Dry Season] and Pesta Menyambut Hujan [Feast for the Rain].

To review briefly each book, Menyambut Mentari tells of a fertile village inhabited by animals and plants that help each other and depend on each other. 
The lesson-learned herein is that we must make the slightest into major changes that will help make our environment healthier now and in the future. To be healthy we have to live in healthy environment. The sweltering earth is the message delivered in Kering Kemarau. This book is the second part of the series to remind readers that all life on the planet has the basic necessities. Every being is unique and special. We all need to materialize each other's basic needs instead of fighting with one another. We can do so by respecting and accepting differences, taking care of and supporting each other. Diharja's third book, Pesta Menyambut Hujan is a conservation story. "Save the chain of life and be grateful for the mercy of nature" is the message. Every creature must look after and not destroy each other. Furthermore, people are essential to maintain the balance of nature. Pollution and trash culture is a systematic destruction of nature by living creatures called human beings.

Writing books for children or young adults is more difficult than for the general readers because the use of language and contents of the book are to suit the children's level of development. Children's literature is a blend of imagination, emotion, vision and mission if the task thereof is to grow wholesome individuals and good citizens. Revealing the ugly realities in books for children is not always easy, but doing otherwise will only create escapist society that ignores responsibility and human dignity. Thus, the writing project achieves this end by paying attention to (1) target readers, (2) narrative technique and (3) presentation of the book.

The first is to whom the book is addressed. The Harry Potter books, widely-read by adults and children alike, to quote Perry Nodelman, are "perhaps the only children's literature adults can read without shame [making] them unlike other children's books - but also unlike other adult books" (2008: 339). Similarly, in terms of target readership, Prapta Diharja's books fall into the same category, i.e. written to please as well as awaken the mind of the young readers as well as adults about the world they live in. Set in supposedly a region in Indonesia (using Javanesesound-name like "Sumberejo" or source of wealth), the series send ecological message across to the readers that the country is indeed a storehouse of species, carbon, water storage, to say nothing of the vast mineral resources, but is now under threat. Such an issue is neither "quite for children" nor "quite for adults". Environmental conservation is not an adultonly-topic. Knowledge about human actions that cause illegal loggings, deforestations, floods, landslides and other calamities is nowadays general truth. People young and old understand and admit the problem of natural resources in Indonesia. Pope
Francis' call for ecological justice is all the more relevant in Indonesia. Only small number of local residents has thus far taken advantage of the country's wealth of biodiversity that are sold out, often at low price, for export. This is to say that environmental issues are significant to discuss by all with varying degrees of depth from science, social culture, economy and politics to everyday lifestyles such as energy saving and use of plastic bags. As it is, the series can serve as supplementary materials for extensive reading at school levels.

The second is how such concerns are told to the readers. Animals are common characters in any accounts about environment. Not only do animal characters enrich and broaden imagination, they also reduce stereotyping and patronizing tendency. Birds of different colours and feathers, for example, are present in Pesta Menyambut Hujan so as to help us imagine the company of great variety of living creatures around us. That these animals could talk, again, helps stretch our imagination that they too, similar to human beings, have the rights to live without harm. When such characters look selfish, nonchalant or simply ignorant like Bangau (crane) who later befriends with Keong (snail) in Menyambut Mentari, for example, nobody is hurt for being told about the folly of greed. Besides, books for children are peopled with cats, dogs, rabbits, elephants, etc. because they are funny and help the young mind to learn about care and compassion.

Human characters in the series are a few - they are Pak Tani, Bu Tani and Pak Kadus. None of them play significant roles as they become minor characters in the animal kingdom. The farmers in Kering Kemarau experience difficulties during the dry season because the prolonged drought fails their harvest. We are told about this bad news by the animals gathering by the small pond for their regular morning discussion. The village head in Pesta Menyambut Hujan, nonetheless, is important because this character, upon witnessing the depletion of natural resource via the story of Monyet (monkey) takes action by holding a selamatan (Javanese thanksgiving ceremony) to appease all living creatures. Pak Kadus is there in the story to get the events going.

Thus, the use of personification or anthropomorphism as a literary device in the series helps the author to convey moral lessons without moralizing. No fingerpointing at the real life actors in illegal logging, shameless polluters, greedy developers and corrupt leaders is necessary here because these crimes are seen "only" through the eyes of the animals - the far wiser and more ecologically conscious characters than people. 
The third technique used by Prapta Diharja is the unusual way the series are presented. Each of Alamku, Sayang series contains story, questions for discussion, eco trivia and reflection-action component. Each nicely coloured and illustrated book is a finished story, but given the similar setting, the books that consecutively come later can be seen as sequels. Unlike the ordinary story books, the series have interaction components for the readers. While the-10questions for discussion and did-you-know-information are added after the end of the story are meant to assess the readers' cognitive understanding, the reflection and action part is for real life applications of the knowledge. Most young people today spend hours immersing in activities that involve engaging themselves in social media, playing video games, watching television and videos, surfing the Internet, etc. In short, today's people in the formative years are overexposed to senseless violence in real life as depicted in social media, thus becoming insensible of their physical and social environments. The suggested activities for reflection and action are provided in the serials in the hope to break such ecological ignorance.

\section{CONCLUSIONS}

Today's children and youth are growing up in a world of ecological crisis. This study has shown that eco education is thus necessary to empower them to make changes and save the Earth, our common home, fit to live in for us and all other creatures by reading green stories, i.e. such environmental narratives as short stories, fables, folklores, etc. Ecological stories set in Asia are scarce and writing such stories is part of the project reported herein, mindful of the fact that children have the agency and responsibility to save the earth through the books they enjoy reading. Reading stories about people and nature set in the West may sometimes give children from nonWestern culture some sense of dislocation with which the ecological message likely fails to come across. As such, evocation of stories that are close to one's own sense of experience and space is of an important issue in Postcolonial situation. Recognition of Asian stories, choice of local settings and appreciation of nonWestern wisdom and knowledge are characteristics of counter-discursive reading (and rewriting) in Postcolonial criticism adopted in this study.

By examining several stories about people and nature, this article has also shown that the stories discussed are not fully ecological stories because many of them are morality tales that touch on environmental issues. Accordingly, most stories are human-centered and serve the interests of people to use and rule nature only to abuse it in the end. Using Ecocritical and
Postcolonial perspectives, the analysis has shown that the narrative threads of the stories are as follows, (1) the depletion of the earth and its natural resources, (2) people's greed in using and abusing nature, and (3) maintenance of the traditional wisdom to save the earth. It would seem that stories set in Asia are rich in moral values with which the ecological stories under discussion show their "Asian-ness" in addition to their local settings. Consequently, most stories are more people-centered than pro-nature. Imbalanced powerrelations of people and nature and among people are present is several stories.

Indeed, such unjust relationships addressed in the stories are resonant in Papal Encyclicals Laudato si' about global imbalance to be solved by people around the world including children. As such, good reading materials used in eco education can be of some help.

It has also been shown in this article that the use of animal characters is dominant in the 16 environmental stories analyzed and that of Alamku, Sayang trilogy. Given the often one-sided nature of animal characters be it positive (futuristic, thrifty, considerate, etc.) or negative (sly, naughty, selfish, etc.), there is a danger that such characters can be easily accepted without seeming weird. Animal characterization is less intricate when compared to possible complexities found in human characters. However, a story with animal characters has the advantage of offering makebelieve accounts in objective and non-patronizing mode. This narrative technique is well-suited with the goal to achieve in environmental education for young people by making use of storytelling, despite the anthropocentric inclination it entails. As such, the use of animal characters with more roles and involvedness is attempted in the writing project.

\section{REFERENCES}

Ashcroft, B., Griffiths, G. \& Tiffins, H. (1989). The empire writes back: Theory and practice in post-colonial literatures. London: Routledge.

Ashcroft, B. Postcolonial transformation. (2001). London: Routledge.

Bradford, C. (2007). Unsettling narratives: Postcolonial readings of children's literature. Canada: Wilfrid Laurier University Press.

Dewi, N. (2015). Manusia dan lingkungan dalam cerpen Indonesia kontemporer: Analisis ekokritik cerpen pilihan Kompas [People and environment in contemporary Indonesian short stories: Ecocritical analysis on Kompas selected short stories]. LITERA, 2 (14), 376-391. http://journal.uny.ac.id/index.php/litera/article/ view/7211/6216 
Donelson-Sims, D. E. (2013). Stuck in a moral prison: Exploring the roots of why Indonesian students moralize literature. $k @$ ta: A Biannual Publication on the Study of Language \& Literature, 15 (2), 101-108. DOI: 10.9744/ kata.15.2.101-108

Diharja, P., S. J. Menyambut mentari. Yogyakarta: Sanata Dharma University Press, 2016. ISBN 978-602-74881-3-7

Diharja, P., S. J. Kering kemarau. Yogyakarta: Sanata Dharma University Press, 2016. ISBN 978602-74881-5-1

Diharja, P., S. J. Pesta menyambut hujan. Yogyakarta: Sanata Dharma University Press, 2016. ISBN 978-602-74881-7-5

Ellis, Brian "Fox". (2012). Learning from the land: Teaching ecology through stories and activities, $2^{\text {nd }}$ Edition. Santa Barbara: ABC-CLIO, LLC.

Gaard, G. (2009). Children's environmental literature: From ecocriticism to ecopedagogy. Neohelicon, 36 (2), 23-39. DOI: 10.1007/s11059009-0003-7

Huggan, G \& Tiffin, H. (2010). Postcolonial ecocriticism: Literature, animals, environment. London: Routledge.

Lindenpütz, D. (2016, October). Children's literature as a medium of environmental education. The culture of German environmentalism: Anxieties, visions, realities. Ed. A. Goodbody, $187-$ 202.

Livo, Norma J. (2003). Bringing out their best: Values education and character development through traditional tales. Westport, CT: Libraries Unlimited.

MacDonald, Margaret Read. (1999). Earth care: World folktales to talk about. Atlanta: August House Publisher. . (2003). Cerita-cerita pelestarian lingkungan: Cerita rakyat dari berbagai penjuru dunia. Trsl. F. C. Wardani. Yogyakarta: Penerbit Kanisius.
Marzec, Robert P. (2007). An ecological and postcolonial study of literature: From Daniel Defoe to Salman Rushdie. New York: Palgrave Macmillan.

Massey, Geraldine. (2009). Reading the environment: Narrative constructions of ecological subjecttivities in Australian children's literature, Unpublished Ph.D Thesis, Queensland University of Technology.

Nodelman, Perry. (2008). The hidden adult: Defining children's literature. Baltimore: Johns Hopkins University Press.

O'Brien, Kathy, and Darleen K. Stoner. (1987). "Increasing environmental awareness through children's literature" The Reading Teacher, 41 (1), 14-19. Retrieved from http://www.jstor. org/stable/20199688.

Parkinson, Rob. (2009). Transforming tales: How stories can change people. London: Jessica Kingsley Publishers.

Pope Francis. (2015). Encyclical letter laudato si' of the Holy Father Francis on care for our common home. Vatican City: Libreria Editrice Vaticana.

Ramos, Rui and Ana Margarida Ramos. (2015). Children's literature and the promotion of environmental ethics in Portugal. Portuguese Studies, 31 (1), 94-106.

Strickland, Tessa. (2009, Spring). Stones, woods and water: Deep ecology and children's literature. IBBYLink, 24, 6-8 Retrieved from https://www. google.co.id/?gws_rd=cr\&ei=Ksf1V6_oHMX F0gTUpaOwBQ\#q=children $\% 27 \mathrm{~s}+$ literature+ and+ecocriticism+jstor

Tantri Novianti. (2014). Putri alor [Princess alor], Kompas Minggu, 7 September, 35.

Tyas K W. (2016). Menanam bakau [Planting mangrove], Kompas Minggu, 24 Juli, 19.

Wahyu Indriati. (2016), Warisan mbah Amat [The inheritance of mbah Amat], Kompas Minggu, 9 October, 10. 